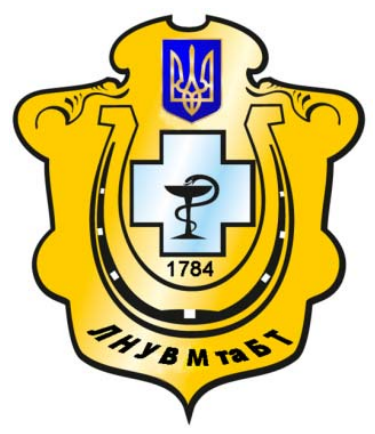

Науковий вісник Львівського національного університету ветеринарної медицини та біотехнологій імені С.3. Гжицького

Scientific Messenger of Lviv National University of Veterinary Medicine and Biotechnologies named after S.Z. Gzhytskyj

doi:10.15421/nvlvet6606

ISSN 2413-5550 print

ISSN 2518-1327 online

$\underline{\text { http://nvlvet.com.ua/ }}$

УДК 619:616.98:579

\title{
Еволюція патогенності Clostridium chauvoei
}

\author{
В.О. Бусол ${ }^{1}$, М.С. Мандигра ${ }^{2}$, П.К. Бойко ${ }^{2}$, Б.М. Куртяк ${ }^{3}$ \\ vishev08@ukr.net,pkbyko@ukr.net,kurtakbohdan@gmail.com \\ ${ }^{1}$ Національний університет біоресурсів і природокористування Украӥни, \\ вул. Героїв Оборони, 11, м. Київ, 03041, Україна; \\ ${ }^{2}$ Інститут ветеринарної медицини НААН Украӥни, \\ вул. Донецька, 30, м. Київ, 03151, Україна; \\ Львівський національний університет ветеринарної медицини та біотехнологій імені С.З. Гжицького, \\ вул. Пекарська, 50, м. Львів, 79010, Украӥна
}

На основі результатів багаторічних досліджень епізоотологічного моніторингу емфізематозного карбункулу у світі та в Украӥні встановлено, щя збудник інфекиї має повсюдне (на всіх континентах за винятком Антарктики) розповсюдження. Широке і нерівномірне розповсюдження хвороби на території Украӥни, в ії областях та адміністративних районах дає підставу відзначити наявність в певних регіонах сприятливих умов для природної ијикуляиії збудника і відсутність їх в інших. Встановлено, щчо на формування неблагополучних території впливають природно-географічні умови, зокрема щільність трунтоутримуючих відкладів, рівень залягання перших водоносних горизонтів, тип трунтів, інтенсивність ведення меліоративних робіт, а неблагополучні зони головним чином розташовуються в басейнах розливу річок та меліоративних систем, що вказує на локальне розповсюдження збудника емфізематозного карбункулу.

У зразках трунту худобомогильників, де були захоронення емкарних трупів, виділено ізолят Cl. сhаимоеі із товщі добре збереженої тазової кістки трупа бугая, щчо знаходилася на глибині 140-160 см, який володів типовими культуральнобіохімічними і вірулентними властивостями. На нашу думку, тривале збереження життєздатності спор збудника емкару та його вірулентних властивостей пов'язане із тим, щзо на худобомогильниках, які розташовані на пластах жовтої глини, створюються умови, за яких розмноження збудника емкару неможливе, а тому він впродовж багатьох років зберігає свої вірулентні властивості.

Встановлено, ще ізоляти $\mathrm{Cl}$. сhаиvоеі, виділені із трунту неблагополучних щедо емкару пасовищ, помітно знижують свої вірулентні властивості, але повністю їх не втрачають, даючи підставу припустити, щьо у поверхневих шарах трунту пасовищ спрацьовуе інший механізм збереження збудника, який веде до зниження його вірулентних властивостей. Роль кожної із цих різновидностей у системі «паразит - господар» є неоднаковою, а отже й значення кожної з них у підтримиі епізоотичного прочесу теж не рівноцінне.

Ключові слова: Clostridium chauvoеi, еволючія клостридій, патогенність, емфізематозний карбункул, клостридіози, інфекиійні хвороби, саморегулячія епізоотичного процесу, екологія клостридій.

\section{Эволюция патогенности Clostridium chauvoei}

\author{
В.А. Бусол, М.С. Мандигра ${ }^{2}$, П.К. Бойко ${ }^{2}$ Б.М. Куртяк ${ }^{3}$ \\ vishev08@ukr.net,pkbyko@ukr.net,kurtakbohdan@gmail.com \\ ${ }^{1}$ Национальный университет биоресурсов и природопользования Украинь,, \\ ул. Героев Обороны, 11, Киев, 03041, Украина; \\ Институт ветеринарной медицины НААН Украинь, г. Киев \\ ул. Донечкая, 30, г. Киев, 03151, Украина;
}

Львовский национальный университет ветеринарной медицины и биотехнологий имени С.3. Гжицкого, ул. Пекарская, 50, г. Львов, 79010, Украина

\section{Citation:}

Busol V.O., Mandugra M.S., Boyko P.K., Kurtyak B.M. (2016). Evolution of patogenicity clostridium chauvoei. Scientific Messenger LNUVMBT named after S.Z. Gzhytskyj, 18, 2(66), 24-29. 
На основании результатов эпизоотологического мониторинга эмфизематозного карбункула в мире и в Украине установлено, что возбудитель инфекиии имеет повсеместное (на всех континентах за исключением Антарктики) распространение. Широкое и неравномерное распространение болезни на территории Украины, в ее областях и административных районах дает основание отметить наличие в определенных регионах благоприятных условий для естественной ичиркуляции возбудителя и отсутствие их в других.

Установлено, что на формирование неблагополучных территорий влияют естественно-географические условия, в частности плотность почвообразующих отложений, уровень залегания первых водоносных горизонтов, тип почв, интенсивность ведения мелиоративных работ, а неблагополучные зоны, главным образом, располагаются в бассейнах разлива рек и мелиоративных систем, что указывает на локальное распространение возбудителя эмфизематозного карбункула.

В образцах почвы с скотомогильников, где были захоронения эмкарных трупов, выделен изолят Сl. сhаиуоеі из толщи хорошо сохраненной тазовой кости труппа бугая, которая находилась на глубине 140-160 см, который владел типичными культурально-биохимическими и вирулентными свойствами. По намему мнению, длительное сохранение жизнеспособности спор возбудителя эмкара и его вирулентных свойств связано с тем, что на скотомогильниках, которые расположены на пластах желтой глины, создаются условия, за которых размножение возбудителя эмкара невозможно, и потому он на протяжении многих лет сохраняет свои вирулентные свойства.

Установлено, что изоляты Cl. сhаичоеі, выделенные из почвы неблагополучных по эмкару пастбищ, заметно снижают свои вирулентные свойства, но полностью их не теряют, давая основание допустить, что в поверхностных слоях почвы пастбищ срабатывает другой механизм сохранения возбудителя, который ведет к снижению его вирулентных свойств. Роль каждой из этих разновидностей в системе «паразит - хозяин» является неодинаковой, а следовательно и значение каждой из них в поддержке эпизоотического процесса тоже не равноценное.

Ключевые слова: эволючия клостридий, патогенность, эмфизематозный карбункул, инфекционные болезни, саморегуляциия эпизоотического проиесса, экология клостридий.

\title{
Evolution of patogenicity clostridium chauvoei
}

\author{
V.O. Busol ${ }^{1}$, M.S. Mandugra ${ }^{2}$, P.K. Boyko ${ }^{2}$, B.M. Kurtyak ${ }^{3}$ \\ vishev08@ukr.net, pkbyko@ukr.net, kurtakbohdan@gmail.com \\ National University of life and environmental sciences of Ukraine, \\ Heroyiv Oborony Str., 11, Kyiv, 03041, Ukraine; \\ Institute of veterinary medicine of Ukraine, \\ Donetska Str., 30, Kyiv, 03151, Ukraine; \\ ${ }^{3}$ Lviv National University of Veterinary Medicine and Biotechnologies named after S.Z. Gzhytskyi, \\ Pekarska Str., 50, Lviv, 79010, Ukraine
}

Based on years of research epizootic monitoring of Gangraena Emphysematosa in the world and in Ukraine it has been established that the infectious agent is of widespread distribution (in all continents except Antarctica). A wide and uneven spread of the disease in Ukraine territory, in its regions and administrative districts gives grounds to note the presence in certain regions of favorable conditions for the natural circulation of the pathogen and the lack of them in others.

It is established that the formation of the dysfunctional territory affected by natural-geographical conditions, such as the density of the soil deposits, level of first aquifers, soil type, the intensity of melioration, and dysfunctional zones mainly located in the basins of the river and melioration systems, indicating the local distribution of Blackleg(disease) Gangraena emphysematosa (lat.).

From the burial of farm deadstock, in soil samples was allocated isolate of Sl. Chauvoei in well saved pelvic bones of dead animals, located at a depth of 140-160 cm, who has typical culture-biochemical and virulent properties. In our opinion, the longterm preservation of the viability of spores of Blackleg(disease) Gangraena emphysematosa (lat.) and its virulent abilities associated with the fact that reproduction of the pathogen Blackleg(disease) Gangraena emphysematosa(lat.) is impossible in burials located on the yellow clay layers, but for many years it retains its virulence properties.

Found that isolates $\mathrm{Cl}$. shauvoei isolated from soil on disadvantaged pastures effected by Blackleg(disease) Gangraena emphysematosa (lat.), significantly reduce their virulence properties, but not loses them completely, giving a reason to assume that the surface layers of soil pastures triggered another mechanism of preservation, which leads to lower its virulent properties. The role of each of these varieties in the "parasite - host» is not the same, and therefore the value of each of them in support of the epizootic process is not equivalent.

Key words: Clostridium chauvoei, closridia evolution, pathogenic, Blackleg(disease) Gangraena emphysematosa (lat.), clostridiosis, infection diseases, interrelation of epizootic process, clostridia ecology.

\section{Вступ}

Нові економічні умови господарювання в аграрному секторі, реорганізація господарських відносин на селі, а також реорганізація самої служби ветеринарної медицини в країні потребують нових розробок щодо прогнозування та профілактики заразних захворювань в цілому і сапронозних інфекцій зокрема. Серед останньої групи захворювань великої рогатої худоби значну питому вагу мають захворювання, що викликаються анаеробними мікроорганізмами. Серед них особливе місце займають клостридіози і, зокрема, емфізематозний карбункул (емкар).

Загально-біологічною основою патогенності мікроорганізмів є їх пристосованість до забезпечення свого існування за рахунок особин іншого виду, тобто паразитизм. Багатьом патогенним мікроорганізмам властивий летальний паразитизм, коли популяція мікроба-паразита використовує субстрат господаря як середовище живлення лише один раз. Така форма 
взаємин між паразитом і господарем характерна для клостридіозів і зокрема для емфізематозного карбункулу (Supotnickij, 2000; Jarchuk et al., 2002).

Уявлення про природу ряду інфекційних хвороб в останній час значно розширилися завдяки розгляду їх iз загально-біологічних особливостей, $з$ врахуванням екології коактуючих видів (паразиту і господаря) i природи факторів, що забезпечують взаємодію між ними.

Дослідження еволюції заразних хвороб привели до висновку, що найдавніші жителі Землі - мікроорганізми на перших порах не були патогенними в сучасному розумінні цього явища, а первинна форма обміну речовин була основана на використанні готових органічних речовин абіогенного походження. Автотрофність та сапрофітизм з'явилися на пізніших етапах еволюції (Zhdanov, 1964).

Перехід непатогенної сапрофітної форми в патогенну міг здійснюватися в умовах тривалого спільного існування мікроба та макроорганізму при регулярно повторюваних контактах між ними, за наявності екологічних взаємозв'язків.

Поява в окремих представників сапрофітів патогенних властивостей забезпечувало даній расі мікробів нові умови існування і певні переваги перед співродичами, оскільки воно відкривало шлях у нові екологічні ніші, які багаті біомасою і не засвоєні подібними мікроорганізмами. Харчові зв'язки живих істот, будучи найважливішою формою відношення живого до зовнішнього світу, є разом $з$ тим найбільш давніми шляхами здійснення епідемічних (епізоотичних) процесів (Zhdanov, 1964).

Таким чином, інфекційна хвороба у філогенетичному аспекті, як результат пристосування мікроорганізму до своєрідного існування, охоплює лише першу стадію історичного розвитку інфекційних захворювань. Друга стадія - це процес пристосування макроорганізму до цього нового для нього фактору зовнішнього середовища, який при певних умовах впливу може знижувати життєздатність виду або й загрожувати його існуванню.

Це в повній мірі стосується виникнення і розвитку паразитичної стадії у філогенезі $\mathrm{Cl}$. chauvoei, виникнення та розвиток нерівномірної сприйнятливості в процесі онтогенезу всіх індивідуумів рогатої худоби, як основного господаря $\mathrm{Cl}$. chauvoei, та особливі закономірності розвитку інфекційного та епізоотичного процесів, що грунтуються на засадах еволюційно усталених взаємин між популяціями цього виду клостридій та великої рогатої худоби - як основного господаря (Burgasov and Rumjancev, 1974).

Біологічні особливості збудника емфізематозного карбункулу не зовсім вкладаються у звичайні рамки сучасних уявлень про заразну хворобу як процес взаємодії паразита і господаря. Аксіома, що збудник емкару облігатний паразит, а отже біологічна доцільність патогенних властивостей збудника, їх значимість у забезпеченні продовження виду не ставиться ніким під сумнів, а здатність $\mathrm{Cl}$. chauvoei вести сапрофітний спосіб існування у зовнішньому середовищі та здатність утворювати спори і таким чином забезпе- чувати неперервність існування виду ніким не бралася до уваги.

Аналіз даних літератури показує, що на сьогодні відсутні вичерпні відповіді на найважливіші питання про природу, біологічне значення та історичне походження властивостей, що відповідають за специфічну, виняткову за своїми проявом патогенність $\mathrm{Cl}$. chauvoei, встановлення яких дозволить глибше зрозуміти здатність цього виду мікробів викликати захворювання і на основі цих знань обгрунтовувати заходи специфічної та загальної профілактики.

\section{Матеріал і методи досліджень}

Матеріалом досліджень слугували епізоотична ситуація, інфекційний та епізоотичний процеси, етіологія емфізематозного карбункулу великої рогатої худоби, біохімічні, токсигенні, біологічні та імуногенні властивості $\mathrm{Cl}$. chauvoei.

Методи досліджень: ретроспективний епізоотологічний аналіз; біологічний експеримент; епізоотологічні, клінічні, патолого-анатомічні, бактеріологічні та імунологічні методи.

\section{Результати та їх обговорення}

Життєвий цикл сапронозів складається із двох стадій - фази перебування в макроорганізмі (фаза паразитизму) і фази існування у зовнішньому середовищі (фаза сапрофітизму) (Somov, 1985).

Про те, що збудник емфізематозного карбункулу пов'язаний із сапрофітною та ентобіотичною (здатність розмножуватися і переживати у травному тракті морських свинок і великої рогатої худоби) фазами існування та переживання свідчать дані, отримані нами при вивченні епізоотологічного моніторингу цієї інфекції у світі і в Україні та можливості розмноження $\mathrm{Cl}$. chauvoei у грунті (Busol et al., 2002; Bojko and Kovalenko, 2007).

Епізоотологічний моніторинг емфізематозного карбункулу вказує на повсюдне (на всіх континентах за винятком Антарктики) розповсюдження збудника інфекції. Хвороба має широке і нерівномірне розповсюдження на території України, в іiі областях та адміністративних районах, що дає підставу відзначити наявність в певних регіонах сприятливих умов для природної циркуляції збудника і відсутність їх в інших.

Для підтвердження цього припущення нами проведені просторово-часові дослідження на території Волинської, Івано-Франківської, Львівської та Рівненської областей за період з 1948 по 2006 роки (58 років) (Busol et al., 2002; Busol et al., 2003). Встановлено, що на формування неблагополучних території на тій чи іншій місцевості впливають природногеографічні умови, зокрема щільність грунтоутримуючих відкладів, рівень залягання перших водоносних горизонтів, тип грунтів, інтенсивності ведення меліоративних робіт. Поширення інфекції має зональний характер. Як правило, неблагополучні зони формуються в басейнах розливу річок та меліоративних систем, що вказує на локальність розповсюдження 
збудника емфізематозного карбункулу (Busol et al., 2002; Busol et al., 2003).

Для вивчення причин локальності збудника емфізематозного карбункулу з метою виявлення можливого існування циклу розмноження $\mathrm{Cl}$. chauvoei у грунті нами проведено екологічні дослідження.

3 врахуванням даних літератури такі умови можуть бути в грунті (Kovalenko, 1956; Munangandu et al., 1996).

Ймовірно, збудник емфізематозного карбункулу проявляє ознаки життєзабезпечення свого виду в зовнішньому середовищі, зокрема на певній глибині грунту. Спори мікробів з глибинних шарів можуть виноситися на поверхню грунту. Це найчастіше буває в період весняних і літніх повеней та під час проведення меліоративних і земляних робіт.

В попередніх наших дослідах в епізоотичному вогнищі емфізематозного карбункулу була встановлена широка циркуляція збудника емфізематозного карбункулу у зовнішньому середовищі (на поверхні огороджувальних конструкцій ферм, підводах, якими розвозять корми), на поверхні волосяного покриву та у фекаліях великої рогатої худоби (Вojko, 1982).

3 точки зору екології, виявлення збудника емфізематозного карбункулу в тих чи інших грунтових об'єктах представляє значний інтерес. Проте самі по собі ці факти не дають повного уявлення щодо характеру життя цих мікроорганізмів у конкретному абіотичному середовищі, яке забезпечує вегетування та збереження біологічних властивостей бактерій цього роду $\mathrm{i}$, перш за все, не дозволяє оцінити грунт як джерело патогенних клостридій. Для відповіді на це питання було проведено ряд досліджень щодо тривалості зберігання $C l$. chauvoei на різних глибинах грунту худобомогильників, пасовищ, приміщень і території ферм, де спостерігалися спалахи емфізематозного карбункулу (Bojko, 2005).

Із 64 зразків грунту, відібраних із чотирьох худобомогильників, розташованих у різних районах Волинської області, культуру C. chauvoei виділено в лише одному випадку - с. Коршівець Луцького р-ну, де 17 років тому спостерігали спалах емфізематозного карбункулу. Ізолят виділено із товщі добре збереженої тазової кістки трупа бугая, що знаходилася на глибині 140-160 см. Культура ізоляту володіла типовими для $\mathrm{Cl}$. chauvoei тинкторіальними, морфологічними та культурально-біохімічними властивостями і була високо вірулентною для морських свинок. На нашу думку, таке тривале збереження життєздатності спор збудника емкару та його вірулентних властивостей пов'язане із тим, що худобомогильник (с. Коршівець Луцького p-ну) розташований на потужному пласті жовтої глини, яка під впливом опадів ніби законсервувала або сповільнила гнильні процеси, а отже, повний розпад всіх тканин, і кісткової зокрема.

Таким чином, спорова форма $\mathrm{Cl}$. chauvoei, якщо вона під впливом тих чи інших факторів не переходить у вегетативну форму, зберігає вихідні тинкторіальні, морфологічні, біохімічні та вірулентні властивості, не залежно від терміну їх зберігання, а емкарні трупи тварин, закопані на худобомогиль-никах, що розташовані на значних глинистих пластах, можуть складати тривалу потенційну загрозу виникнення спалахів емфізематозного карбункулу.

При дослідженні 78 зразків грунту із неблагополучних щодо емкару пасовищ, ізоляти $C l$. chauvoei виділено iз 12 зразків. Жоден із них не викликав смерті морських свинок у дозах рутинного лабораторно зараження (1 см ${ }^{3}$ 24-годинної культури на середовищі Кітт-Тароцці, уведений підшкірно в ділянці паху).

Вивчення ступеня втрати патогенності пасовищних ізолятів показало, що, перебуваючи у поверхневих шарах грунту пасовищ, $\mathrm{Cl}$. chauvoei помітно знижує свої вірулентні властивості, але повністю їх не втрачає. Можна думати, що у поверхневих шарах грунту пасовищ, звідки було виділено ізоляти, спрацьовує інший механізм збереження збудника, який веде до зниження його вірулентних властивостей. Таке явище ми спостерігали, коли вірулентні музейні штами $C l$. chauvoei тривалий час пересівати із середовища на середовище і не проводити через організм сприйнятливих тварин (морських свинок). Про аналогічну закономірність повідомляють Е.Ш. Акопян (Akopjan, 1952), Драганов М., Пейчев Б. (Draganov and Pejchev, 1968), Кирилов Л.В. и др. (Kirillov, 2001), Ляушкин А.B. (Ljaushkin, 1971).

В дослідах 3 вивчення можливості розмноження Cl. chauvoei в різних типах грунтів нами встановлено, що чорноземні грунти гідроморфного походження природних лучних пасовищ, які мають незруйнований верхній шар, можуть виступати як середовище розмноження збудника емфізематозного карбункулу. Отримані дані дають підставу вважати грунт джерелом збудника інфекції, а емфізематозний карбункул сапронозною інфекцією.

Треба відзначити, що рослинний покрив являє собою потужний олігодинамічний фактор формування мікробного співтовариства грунту. Вплив вищих рослин на мікробні ценози грунту дуже різноманітний (Golovko, 1990). Зокрема, на різних ділянках сінокосів і пасовищ $з$ природним травостоєм проростає одночасно багато рослин, які утворюють рослинні сукупності, або фітоценози. Біологічні відносини складаються iз взаємних або односторонніх впливів кореневих, листяних та інших виділень рослин. Взаємовплив між рослинами у фітоценозі може здійснюватися не лише через середовище, але й через посередність грунтових мікроорганізмів - бактерій та грибів (Vavulo, 1972).

В поверхневому шарі лучного грунту корені рослин, пагони та кореневища утворюють дернину, в якій розвиваються гриби, бактерії і мезофауна, що використовують багато кисню. Тому більш глибокі шари грунтового профілю залишаються недоокисленими, що сприяє анаеробіозу та накопиченню органічної речовини. На лучних грунтах з ослабленою аерацією i підвищеним вмістом вуглекислоти анаеробні мікроорганізми переважають над аеробними (Kijak, 1986). Очевидно, останнє має вирішальний вплив на виживання збудника емфізематозного карбункулу у зовнішньому середовищі, і є визначальним фактором сапрофітної фази його розвитку.

Таким чином, в абіотичному середовищі популяція Cl. chauvoei за вірулентністю є гетерогенною і склада- 
ється із двох різновидностей - одна високо вірулентна, але порівняно не чисельна, і друга - більш поширена в певних природно-географічних зонах, але слабо вірулентна. Завдяки існуванню двох різновидностей $C l$. chauvoei формується, підтримується і регулюється неблагополуччя на інфікованих територіях. Роль кожної із цих різновидностей у системі «паразит господар»є неоднаковою, а отже й значення кожної 3 них у підтримці епізоотичного процесу теж не рівноцінне.

Зважаючи на поширення збудника емфізематозного карбункулу на території всіх континентів світу, його однотипну антигенну структуру, схожість патогенезу, клінічного прояву та патологоанатомічних змін у різних видів тварин, можна припустити, що еволюція патогенних властивостей $C l$. chauvoei відбувалася одночасно і за одним сценарієм на всіх континентах світу.

В той же час на окремо взятій неблагополучній території спостерігаємо зміну вірулентних властивостей, на що вказує гетерогенність популяції мікроорганізму за такою важливою ознакою як патогенність.

Таким чином, поряд з такими досить стабільними (постійними) видовими ознаками, як облігатність анаеробіозу, вибагливість до ростових потреб, однотипність антигенної структури та біохімічної активності спостерігаємо дуже мінливу константу вірулентності, яка, як було встановлено нашими дослідженнями, залежить від токсигенної активності мікроорганізму, яка є лабільною і обумовлюється активністю ферментів екзотоксину, зокрема, гемолізину, гіалуронідази, дезоксирибонуклеази, летального токсину, очевидно й ряду інших (Akymenko and Bojko, 2007).

Можна стверджувати, що постійні ознаки фізіології та біохімії $\mathrm{Cl}$. chauvoei сформулювалися на ранніх етапах еволюції, тоді як мінливі, зокрема, вірулентність та фактори, що іiі обумовлюють, на пізніших етапах, в період, коли сформувалася популяція великої рогатої худоби, і взаємини мікроорганізму із цим видом теплокровних тварин стали постійними.

\section{Висновки}

1. Емкарні трупи тварин, закопані на худобомогильниках, що розташовані на значних глинистих пластах, можуть складати тривалу потенційну загрозу виникнення спалахів емфізематозного карбункулу.

2. Перебуваючи у поверхневих шарах грунту пасовищ, $\mathrm{Cl}$. chauvoei помітно знижує свої вірулентні властивості, але повністю їх не втрачає.

3. Чорноземні грунти гідроморфного походження природних лучних пасовищ, які мають незруйнований верхній шар, можуть виступати як середовище розмноження збудника емфізематозного карбункулу. Це є підставою вважати грунт другою різновидністю джерела збудника інфекції, а емфізематозний карбункул сапронозною інфекцією.

4. Хвора на емфізематозний карбункул тварина не $\epsilon$ біологічним тупиком для збудника інфекції, і в цей же час нами не встановлено контактного шляху зараження тварин. Це свідчить про те, що виникнення нових інфекційних процесів при емкарі пов'язане одне 3 одним через абіотичні об'єкти довкілля (грунт).

5. Розкриваючи еволюцію причинно-наслідкових взаємин між збудником емфізематозного карбункулу, як сформованим факультативним паразитом, та його господарем - великою рогатою худобою, можна пояснити еколого-біологічну доцільність явища мінливості вірулентних властивостей $\mathrm{Cl}$. chauvoei.

6. Взаємодія гетерогенних популяцій $C l$. chauvoei та великої рогатої худоби на засадах факультативного паразитизму уможливлює подальшу еволюцію їх взаємин, забезпечуючи тим самим саморегуляцію епізоотичного процесу емфізематозного карбункулу.

\section{Бібліографічні посилання}

Jarchuk, B.M., Verbyc'kyj, P.I., Lytvyn, V.P. (2002). Zagal'na epizootologija. Bila Cerkva (in Ukrainian).

Supotnickij, M.V. (2000). Mikroorganizmy, toksiny i jepidemii. M.: Vuzovskaja kniga (in Russian).

Zhdanov, V.M. (1964). Jevoljucija zaraznyh boleznej cheloveka. M.: Medicina (in Russian).

Burgasov, P.N., Rumjancev, S.N. (1974). Jevoljucija klostridiozov. M.: Medicina (in Russian).

Somov, G.P. (1985). Joshhe raz o sapronozah. ZhMJeI. 5, 98-104 (in Russian).

Busol, V.O., Postoj V.P., Bojko P.K. (2002). Monitoryng epizootychnoi' sytuacii' $\mathrm{Z}$ emfizematoznogo karbunkulu v sviti. Veterynarna medycyna (Mizhvidomchyj tematychnyj naukovyj zbirnyk). Harkiv: IEKVM. 80, 110-114 (in Ukrainian).

Bojko, P.K., Kovalenko, L.V. (2007). Vegetacija spor Clostridium chauvoei u travnomu trakti mors'kyh svynok ta u g'runti / P. K. Bojko, // Visnyk Bilocerkivs'kogo derzhavnogo agrarnogo universytetu: Zb. nauk. prac'. - Bila Cerkva: BCDAU. 48, 17-195 (in Ukrainian).

Busol, V.O., Ryzhenko, V.P., Gorzhejev, V.M., Bojko, P.K. (2003). Kadastr stacionarno neblagopoluchnyh punktiv z emfizematoznogo karbunkulu na terytorii' Volyns'koi' oblasti (1948-2001 rr.). Kyi'v: Derzhavnyj departament veterynarnoi' medycyny Ukrai'ny (in Ukrainian).

Busol, V.O., Mandygra, M.S., Bojko, P.K. (2002). Vplyv pryrodno-geografichnyh faktoriv na epizootychnyj proces pry emfizematoznomu karbunkuli velykoi' rogatoi' hudoby. Visnyk Bilocerkivs'kogo derzhav. agrarnogo universytetu. Zbirnyk nauk. prac'. Bila Cerkva: BCAU. 21, 32-40 (in Ukrainian).

Kovalenko, Ja.R. (1956). Sohranenie i vegetativnyj rost S. chauvoei $v$ pochve. Trudy VGNKI. 6, 197-200 (in Russian).

Munangandu, H.M., Muyoyeta, P.M., Mcweene, A.S., Kida, H. (1996). Bovine Clostridial infections in Zambia (1985-1994). Japan J. Vet. Res. 44(3), 175178.

Bojko, P.K. (1982). Immunofluorescentnaja identifikacija vozbuditelja jemfizematoznogo karbunkula / Avtoreferat dissertacii na soiskanie uchenoj stepeni kand. vet. nauk. M.: MVA (in Russian).

Bojko, P.K. (2005). Kadastr neblagopoluchnyh punktiv z emfizematoznogo karbunkulu - vazhlyva umova 
efektyvnosti protyemkarnyh zahodiv. Sil's'kyj gospodar. 11-12, 3-6 (in Ukrainian).

Akopjan, E.Sh. (1952). Zhivaja vakcina pri jemfizematoznom karbunkule krupnogo rogatogo skota. Veterinarija. 10, 15-18 (in Russian).

Draganov, M., Pejchev, B. (1968). Zavisimost mezhdu virulenite i immunogenite svojstva na $\mathrm{Cl}$. Chauvoei. Veterinarnomedicinski nauki. 5(8), 33-37. (in Russian).

Kirillov, L.V. (2001). Preduprezhdenie infekcionnyh boleznej anajerobnoj jetiologii. Veterinarija. 1, 16-19 (in Russian).

Ljaushkin, A.V. (1971). Biologicheskie svojstva nevirulentnyh shtammov S. Chauvoei. Trudy VIJeV. 39, 178-183. (in Russian).
Golovko, Je.A. (1990). Gans Molish i sovremennaja allelopatija. Allelopatija i produktivnost' rastenij. Sbornik nauchnyh trudov. Kiev: Naukova dumka (in Russian).

Vavulo, F.P. (1972). Mikroflora osnovnyh tipov pochv BSSR i ih plodorodie. Minsk: Uradzhaj (in Russian).

Kijak, G.S. (1986). Lugovodstvo. Uchebnik dlja s.-h. Vuzov. Kiev: Vishha shkola (in Russian).

Akymenko, L.I., Bojko, P.K. (2007). Pidtrymannja biotehnologichnyh harakterystyk deponovanyh shtamiv - vazhlyva skladova jakosti imunobiologichnyh preparativ. Naukovo-tehnichnyj bjuleten'. 8(3-4), 221-226 (in Ukrainian).

Стаття надійшла до редакиії 23.09.2016 